\title{
ERN1 MODIFIES THE EFFECT OF GLUTAMINE DEPRIVATION ON TUMOR GROWTH RELATED FACTORS EXPRESSION IN U87 GLIOMA CELLS
}

\author{
O. H. MINCHENKO, A. P. KHARKOVA, O. S. HNATIUK, \\ O. Y. LUZINA, I. V. KRYVDIUK, A. Y. KUZNETSOVA \\ Palladin Institute of Biochemistry, National Academy of Sciences of Ukraine, Kyiv; \\ e-mail: ominchenko@yahoo.com
}

The expression of a subset of genes encoding important tumor growth related factors in U87 glioma cells with ERN1 (endoplasmic reticulum to nucleus signaling 1) loss of function as well as upon glutamine deprivation was studied. It was shown that glutamine deprivation down-regulated the expression level of ATF6 (activating transcription factor 6), EIF2AK3/PERK (eukaryotic translation initiation factor 2 alpha kinase 3), GLO1 (glyoxalase I), BIRC5 (baculoviral IAP repeat-containing 5), and RAB5C (RAB5C, a member of RAS oncogene family) mRNAs in control glioma cells. At the same time, the expression level of HSPB8 (heat shock 22kDa protein 8) and HSPA5/GRP78 (heat shock protein family A (Hsp70) member 5) mRNAs was resistant to glutamine withdrawal in these glioma cells. It was also shown that inhibition of ERN1, which controled cell proliferation and tumor growth, modified the effect of glutamine deprivation on the expression levels of most studied genes in U87 glioma cells: up-regulated the expression of ATF6 and HSPA5 genes and enhanced sensitivity of EIF2AK3 and BIRC5 genes to glutamine withdrawal. Furthermore, the expression of all studied genes, except EIF2AK3, was down-regulated in ERN1 knockdown glioma cells in the presence of glutamine. It was demonstrated that glutamine deprivation affected the expression of most studied genes in ERN1 dependent manner and that these changes possibly contributed to the suppression of glioma growth from cells without ERN1 signaling enzyme function.

Ke y wo rd s: glutamine deprivation, ERN1 inhibition, mRNA expression, ATF6, EIF2AK3, BIRC5, RAB5C, HSPA5, U87 glioma cells.

$\mathrm{T}$ he endoplasmic reticulum stress is an important component of tumor growth, including glioblastoma multiforme, which is highly aggressive tumor with very poor prognosis and to date there is no efficient treatment available [1-5]. Its aggressiveness is due to increased invasion, migration, proliferation, angiogenesis, and a decreased apoptosis [6]. Diffuse infiltrating gliomas are the most common tumors of the central nervous system. ERN1/ IRE1 (endoplasmic reticulum to nucleus signaling 1/ inositol requiring enzyme 1) signaling pathway of endoplasmic reticulum stress is a central mediator of the unfolded protein response and inhibition of this signaling pathway leads to a suppression of glioma growth through down-regulation of proliferation processes as a result of metabolic reprogramming of cancer cells [7-10]. The endoplasmic reticulum stress controls the expression of numerous regulatory and proliferation related genes, which are responsible for glioblastoma progression [8, 10-14].

It is well known that glutamine is an important factor of glioma development and a more agressive behaviour $[15,16]$. Furthermore, tumor cells have high-energetic and anabolic needs and are known to adapt their metabolism to be able to survive and support proliferation under conditions of nutrient stress. Recently, Polet et al. [17] found that glutamine withdrawal inhibited leukemia cell growth but also led to a glucose-independent adaptation maintaining cell survival through the up-regulation of two important enzymes of the serine pathway: phosphoglycerate dehydrogenase (PHGDH) and phosphoserine ami-

(C) 2018 Minchenko O. H. et al. This is an open-access article distributed under the terms of the Creative Commons Attribution License, which permits unrestricted use, distribution, and reproduction in any medium, provided the original author and source are credited. 
notransferase (PSAT1). Furthermore, serine is a key pro-survival actor that needs to be handled to sensitize leukemia cells to glutamine-targeting modalities, because it contributed to cell regrowth following glutamine deprivation [17]. It is interesting to note that protein kinase $\mathrm{C}$ epsilon (PRKCE) is a critical metabolic tumor suppressor and its deficiency promotes the plasticity, which is necessary for tumor cells to reprogram their metabolism: utilize glutamine through the serine biosynthetic pathway in the absence of glucose [18]. PRKCE is a calcium-independent serine/threonine-protein kinase that plays essential roles in the regulation of multiple cellular processes linked to cell adhesion, motility, migration and cell cycle and is involved in immune response, cancer cell invasion and regulation of apoptosis. Thus, a better knowledge of tumor responses to glutamine deprivation condition is required to elaborate therapeutical strategies of cell sensibilization, based on the blockade of survival mechanisms.

Previously was shown that glutamine withdrawal affected the expression of several tumor growth related genes and that the effect of glutamine deprivation on most of these genes expression is dependent on ERN1 signaling enzyme function [19-23]. However, the regulation of the expression of many other tumor growth related genes by glutamine deprivation in relation to inhibition of ERN1 to not to be clarified yet. Among them ATF6 (activating transcription factor 6) gene encoding an important transcription factor, which participate in the endoplasmic reticulum stress signaling and controls the transcription of numerous stress responsible genes $[24,25]$. Furthermore, ATF6 activates stress responsible gene expressions and regulates cellular senescence, which is known as an anti-tumor barrier $[5,26]$. Eukaryotic translation initiation factor 2 alpha kinase 3 (EIF2AK3), which also known as PKR-like ER kinase (PERK), is an elF2alpha kinase that inhibits protein translation and is involved in control of cell proliferation and tumorigenesis, in mitochondrial function and apoptosis [27-29]. It is also an important signaling protein of endoplasmic reticulum stress signaling pathways [5].

Glyoxalase 1 (GLO1) is responsible for the formation of S-lactoyl-glutathione from methylglyoxal, a dicarbonyl compound that is produced as a side product during glycolysis and induces the formation of advanced glycation end-products, which are implicated in several pathologies including cancer [30]. Thus, this enzyme is implicated in the progression of human malignancies and is up-regulated in tumor tissues with high metabolic rate [31]. At the same time, there is data that the activity of GLO1 in high stage colorectal cancer is lower compared to low stage ones [32]. Furthermore, knockdown of GLO1 in the cancer cells significantly reduced tumor-associated properties such as migration and proliferation, whereas hypoxia caused inhibition of cell growth of all cells except of those over-expressing GLO1 [33]. There is data that this enzyme drives epithelial-tomesenchymal transition and is responsible for cell transformation into a neoplastic-like phenotype [34]. The heat shock protein family A (Hsp70) member 5 (HSPA5), also known as $78 \mathrm{kDa}$ glucose regulated protein (GRP78) and immunoglobulin heavy chain-binding protein $(\mathrm{BiP})$ protein as well as the heat shock $22 \mathrm{kDa}$ protein 8 (HSPB8), also known as protein kinase $\mathrm{H} 11$ (H11) and small stress proteinlike protein HSP22, plays an important role in tumorigenesis [35-39].

The baculoviral IAP repeat-containing 5 (BIRC5), also known as apoptosis inhibitor 4 (API4) and survivin variant 3 alpha, is overexpressed in most tumors and has dual roles in promoting cell proliferation and preventing apoptosis, in cell cycle regulation [40]. Oncogene RAB5C is a member of RAS oncogene family and its overexpression in pancreatic cancer is associated with cancer progression [41]. There is also data that RAB5C is a target of miR-509 and an important regulator of precursor-B acute lymphoblastic leukemia cell growth because co-expression of the $\mathrm{RAB} 5 \mathrm{C}$ open reading frame without its 3 ' untranslated region blocked the growth-inhibitory effect mediated by miR-509 [42].

The aim of this study was investigation the effect of glutamine deprivation on the expression level of ATF6, EIF2AK3, GLO1, HSPB8, HSPA5, BIRC5, and $R A B 5 C$ genes in $\mathrm{U} 87$ glioma cells on a relation to ERN1 inhibition with hopes of elucidating its mechanistic part in the glioblastoma growth through endoplasmic reticulum stress signaling.

\section{Materials and Methods}

Cell Lines and Culture Conditions. In this study we used two sublines of U87 glioma cells, which are growing in high glucose $(4.5 \mathrm{~g} / \mathrm{l})$ Dulbecco's modified Eagle's minimum essential medium (DMEM; Gibco, Invitrogen, USA) supplemented with glutamine $(2 \mathrm{mM}), 10 \%$ fetal bovine serum (Equitech-Bio, Inc., USA), streptomycin $(0.1 \mathrm{mg} / \mathrm{ml}$; Gibco) and penicillin (100 units $/ \mathrm{ml}$; Gibco) at $37^{\circ} \mathrm{C}$ 
in a $5 \% \mathrm{CO}_{2}$ incubator. One subline was obtained by selection of stable transfected clones with overexpression of vector (pcDNA3.1), which was used for creation of dominant-negative constructs (dnERN1). This untreated subline of glioma cells (control glioma cells) was used as control 1 in the study of effects of glutamine deprivation on the expression level of ATF6, EIF2AK3, GLO1, HSPB8, HSPA5, BIRC5, and $R A B 5 C$ genes. Second subline was obtained by selection of stable transfected clones with overexpression of dnERN1 and has suppressed both protein kinase and endoribonuclease activities of this bifunctional sensing and signaling enzyme of endoplasmic reticulum stress. The expression level of studied nuclear genes encoded mitochondrial proteins in these cells was compared with cells, transfected by vector (control 1). The subline, which overexpress dnERN1, was also used as control 2 for investigation the effect of glutamine deprivation condition on the expression level of studied in cells with inhibited signaling enzyme ERN1 function. Clones were received by selection at $0.8 \mathrm{mg} / \mathrm{ml}$ geneticin (G418) and grown in the presence of this antibiotic at lower concentration $(0.4 \mathrm{mg} / \mathrm{ml})$.

Glutamine deprivation condition were created by changing the complete DMEM medium into culture plates on the medium without glutamine (from Gibco) and plates were exposed to this condition for $16 \mathrm{~h}$. The suppression level of ERN1 both enzymatic activity in glioma cells that overexpress a dominantnegative construct of inositol requiring enzyme-1 was estimated previously $[12,13]$ by determining the phosphorylation of ERN1 and the expression level of XBP1 alternative splice variant (XBP1s), a key transcription factor in ERN1 signaling, using cells treated by tunicamycin $(0.01 \mathrm{mg} / \mathrm{ml}$ during $2 \mathrm{hrs})$. Moreover, the proliferation rate of glioma cells with mutated ERN1 is decreased in 2 fold [13]. Thus, the blockade of both kinase and endoribonuclease activity of signaling enzyme ERN1 has significant effect on proliferation rate of glioma cells.

RNA isolation. Total RNA was extracted from glioma cells as previously described [43]. The RNA pellets were washed with $75 \%$ ethanol and dissolved in nuclease-free water. For additional purification RNA samples were re-precipitated with $95 \%$ ethanol and re-dissolved again in nuclease-free water. RNA concentration and spectral characteristics were measured using NanoDrop Spectrophotometer.

Reverse transcription and quantitative PCR analysis. QuaniTect Reverse Transcription Kit (QIA-
GEN, Germany) and Thermo Scientific Verso cDNA Synthesis Kit (Germany) were used for cDNA synthesis according to manufacturer's protocols. The expression level of ATF6, EIF2AK3, GLO1, BIRC5, RAB5C, HSPB8, HSPA5, and ACTB mRNA were measured in glioma cell line U87 and its subline (clone 1C5) by real-time quantitative polymerase chain reaction using "RotorGene RG-3000" qPCR (Corbett Research, Germany) or "QuantStudio 5 Real-Time PCR System" (Applied Biosystems) and Absolute qPCR SYBRGreen Mix (Thermo Fisher Scientific, ABgene House, Epsom, Surrey, UK). Polymerase chain reaction was performed in triplicate.

The amplification of cDNA of the activating transcription factor 6 (ATF6) was performed using forward primer (5'-TGAACTTCGAGGATGGGTTC- $3^{\prime}$ ) and reverse primer (5'-TCACTCCCTGAGTTCCTGCT-3'). These oligonucleotides correspond to sequences 1510-1529 and 1689-1670 of human ATF6 cDNA (GenBank accession number NM_007348). The size of amplified fragment is $180 \mathrm{bp}$. For amplification of the eukaryotic translation initiation factor 2 alpha kinase 3 (EIF2AK3), also known as PRKR-like ER endoplasmic reticulum kinase (PERK), cDNA we used next primers: forward 5'-TCTGTTCAGCTCTGGGTTGT- $3^{\prime}$ and reverse 5'-CCGAAGTTCAAAGTGGCCAA-3'. The nucleotide sequences of these primers correspond to sequences 946-965 and 1103-1084 of human EIF2AK3 cDNA (GenBank accession number NM_004836). The size of amplified fragment is $158 \mathrm{~b}$. The amplification of cDNA of the heat shock 22kDa protein 8 (HSPB8), also known as protein kinase H11 (H11) and small stress proteinlike protein HSP22, was performed using forward primer (5'-GGCAGGTGGTTCTGTCTCTC-3') and reverse primer $\left(5^{\prime}\right.$-CCAAGAGGCTGTCAAGTCGT-3'). These oligonucleotides correspond to sequences 469-488 and 667-648 of human HSPB8 cDNA (GenBank accession number NM_014365). The size of amplified fragment is $204 \mathrm{bp}$. For amplification of the glyoxalase I (GLO1; EC_number="4.4.1.5") cDNA we used next primers: forward 5'-GCGTAGTGTGGGTGACTCCT-3' and reverse 5'-TCACTCGTAGCATGGTCTGC-3'. The nucleotide sequences of these primers correspond to sequences $61-80$ and 240-221 of human GLO1 cDNA (GenBank accession number NM_006708). The size of amplified fragment is $180 \mathrm{bp}$. The amplification of cDNA for the RAB5C, member RAS oncogene 
family (RAB5C) was performed using forward primer (5'-GAGTCTGCGGTAGGCAAATC-3') and reverse primer (5'-CCCGTGCAAATGTATCTGTG $-3^{\prime}$ ). These oligonucleotides correspond to sequences 285-304 and 534-515 of human RAB5C cDNA (GenBank accession number NM_004583). The size of amplified fragment is $250 \mathrm{bp}$. The amplification of the baculoviral IAP repeat-containing 5 (BIRC5), also known as apoptosis inhibitor 4 (API4) and survivin variant 3 alpha, cDNA was performed using forward primer (5'-GGACCACCGCATCTCTACAT- $\left.3^{\prime}\right)$ and reverse primer (5'-GACAGAAAGGAAAGCGCAAC-3'). These oligonucleotides correspond to sequences 166-185 and 388-369 of human BIRC5 cDNA (GenBank accession number NM_001168). The size of amplified fragment is $204 \mathrm{bp}$. For amplification of the heat shock protein family A (Hsp70) member 5 (HSPA5), also known as $78 \mathrm{kDa}$ glucose-regulated protein (GRP78) and immunoglobulin heavy chain-binding protein (BIP), cDNA we used next primers: forward 5'-GCTGGCAAGATGAAGCTCTC- 3 ' and reverse 5'-ATCAGACGTTCCCCTTCAGG-3'. The nucleotide sequences of these primers correspond to sequences 253-272 and 488-469 of human HSPA5 cDNA (GenBank accession number NM_005347). The size of amplified fragment is $236 \mathrm{bp}$. The amplification of the beta-actin (ACTB) cDNA was performed using forward 5'-GGACTTCGAGCAAGAGATGG-3' and reverse - 5'-AGCACTGTGTTGGCGTACAG-3' primers. These primers nucleotide sequences correspond to 747-766 and 980-961 of human ACTB cDNA (GenBank accession number NM_001101). The size of amplified fragment is $234 \mathrm{bp}$.

The expression of $\beta$-actin mRNA was used as control of analyzed RNA quantity. The primers were received from Sigma-Aldrich (St. Louis, MO, USA). The quality of amplification products was analyzed by melting curves and by electrophoresis using 2\% agarose gel. An analysis of quantitative PCR was performed using special computer program "Differential Expression Calculator". The values of ATF6, EIF2AK3, GLO1, BIRC5, RAB5C, HSPB8, and HSPA5 mRNA expressions were normalized to the expression of $\beta$-actin mRNA and represented as percent of control $1(100 \%)$.

Statistical analysis. All values are expressed as mean \pm SEM from triplicate measurements performed in 4 independent experiments. Statistical analysis was performed according to Student's $t$-test using Excel program as described previously [43].

\section{Results and Discussion}

We have studied the effect of glutamine withdrawal on the expression of genes encoding ATF6, EIF2AK3, GLO1, BIRC5, RAB5C, HSPB8, and HSPA5 proteins, which are related to the regulation of tumor growth, in two sublines of U87 glioma cells in relation to inhibition of ERN1 signaling enzyme. It was shown that glutamine deprivation lead to small, but statistical significant, down-regulation of the expression of ATF6 gene (-14\% as compared to control 1) in control glioma cells (transfected by empty vector) Fig. 1). However, inhibition of ERN1, a major signaling pathway of the unfolded protein response, significantly down-regulates the expression of ATF6 gene in the presence of glutamine (-42\% as compared to control 1 , but strongly increases the

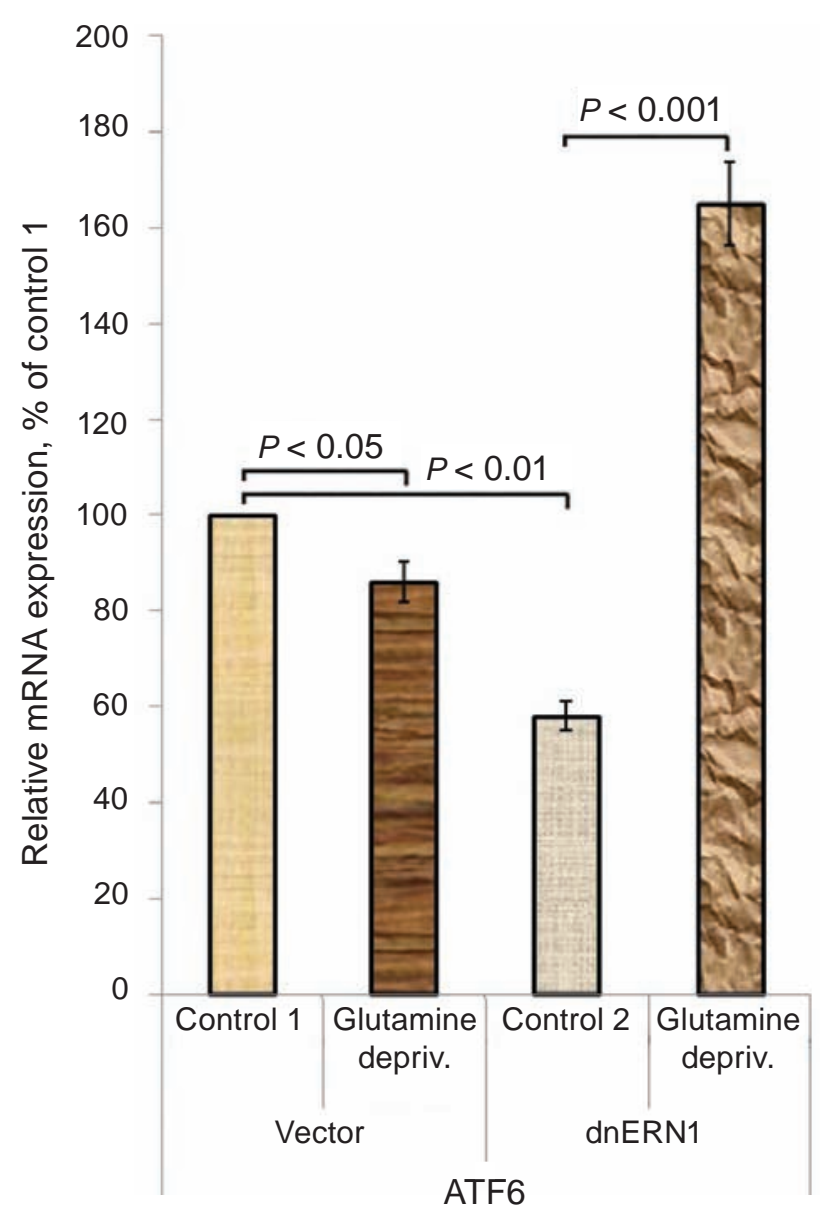

Fig. 1. Effect of glutamine deprivation on the expression level of ATF6 (activating transcription factor 6) mRNA in control U87 glioma cells (Vector) and cells with a blockade of the ERN1 (dnERN1). Values of ATF6 mRNA expressions were normalized to $\beta$-actin $m R N A$ level and represented as percent for control 1 (100\%); $n=4$ 
sensitivity of ATF6 gene expression to glutamine deprivation condition as well as modifies the direction of changes $(+184 \%$ as compared to control 2 ; Fig. 1).

As shown in Fig. 2, the expression level of EIF2AK3/PERK gene is also slightly but statistical significant down-regulated (-13\%) in control glioma cells. However, the suppression of ERN1 signaling enzyme function significantly enhances the sensitivity of this gene expression to glutamine withdrawal in glioma cells: the level of EIF2AK3 gene is decreased more than in two fold in comparison to control 2. At the same time, the expression of this

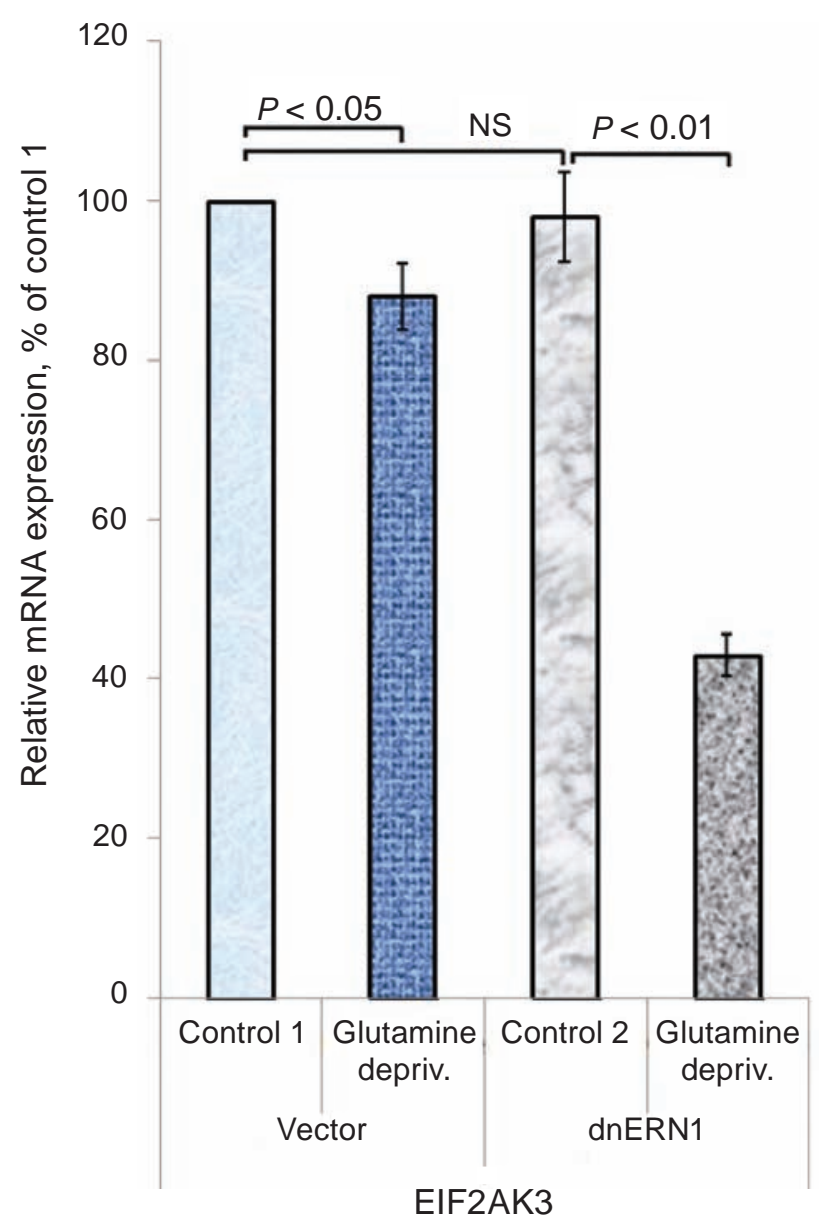

Fig. 2. Effect of glutamine deprivation on the expression level of EIF2AK3 (eukaryotic translation initiation factor 2 alpha kinase 3), also known as PERK (PRKR-like endoplasmic reticulum ER kinase), mRNA in control U87 glioma cells (Vector) and cells with a blockade of the ERN1 (dnERN1). Values of EIF2AK3 mRNA expressions were normalized to $\beta$-actin $m R N A$ level and represented as percent for control 1 (100\%); $n=4$

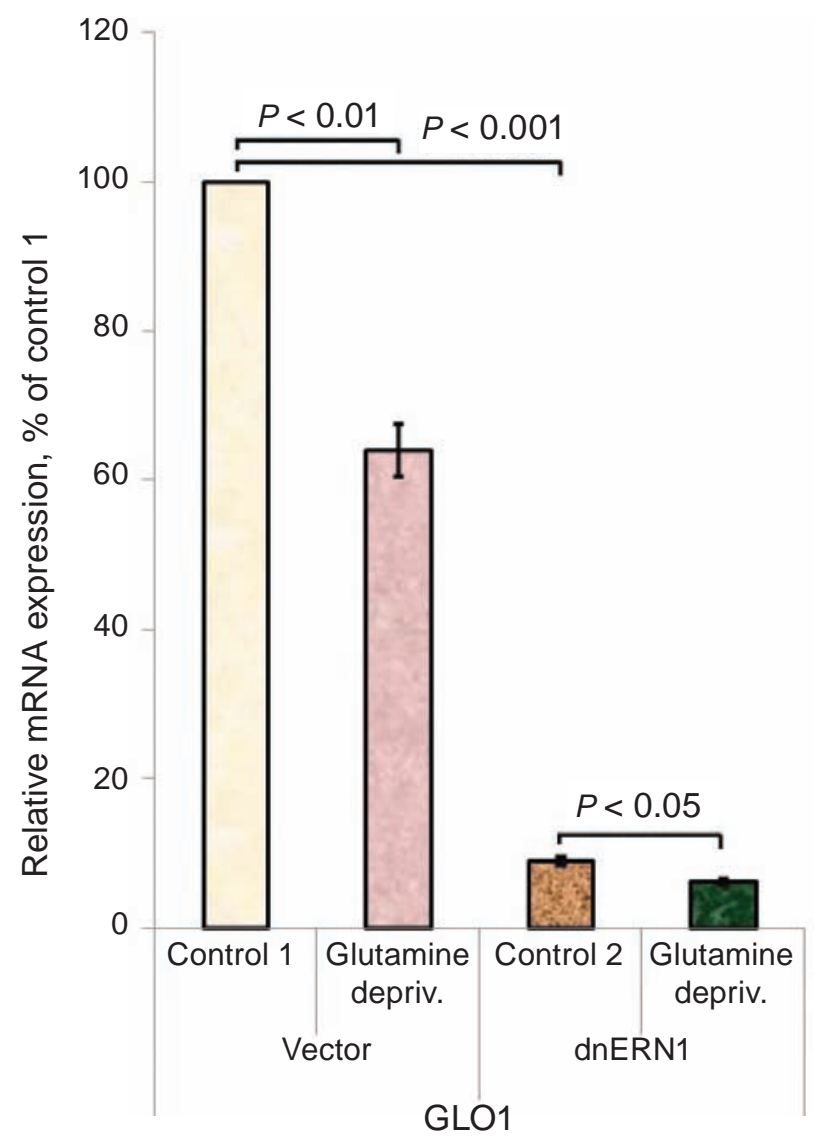

Fig. 3. Effect of glutamine deprivation on the expression level of GLO1 (glyoxalase I) mRNA in control U87 glioma cells (Vector) and cells with a blockade of the ERN1 (dnERN1). Values of GLO1 mRNA expressions were normalized to $\beta$-actin $m R N A$ level and represented as percent for control 1 (100\%); $n=4$

gene is resistant to the inhibition of ERN1 signaling enzyme in glioma cells growing with glutamine (Fig. 2).

Next, we have shown that glutamine deprivation down-regulated the expression of GLO1 gene both in control as well as ERN1 knockdown glioma cells: -36 and $-31 \%$, correspondingly (Fig. 3). Thus, inhibition of ERN1 did not significantly change the effect of glutamine withdrawal on the expression of GLO1 gene. Furthermore, inhibition of ERN1, a major signaling pathway of the unfolded protein response, strongly down-regulates the expression of GLO1 gene in glioma cells growing with glutamine (-91\% as compared to control 1; Fig. 3).

As shown in Fig. 4 and 5, glutamine deprivation down-regulates the expression of genes for BIRC5 and RAB5C (both -24\%) in control U87 glioma cells, but inhibition of ERN1 signaling enzyme function 


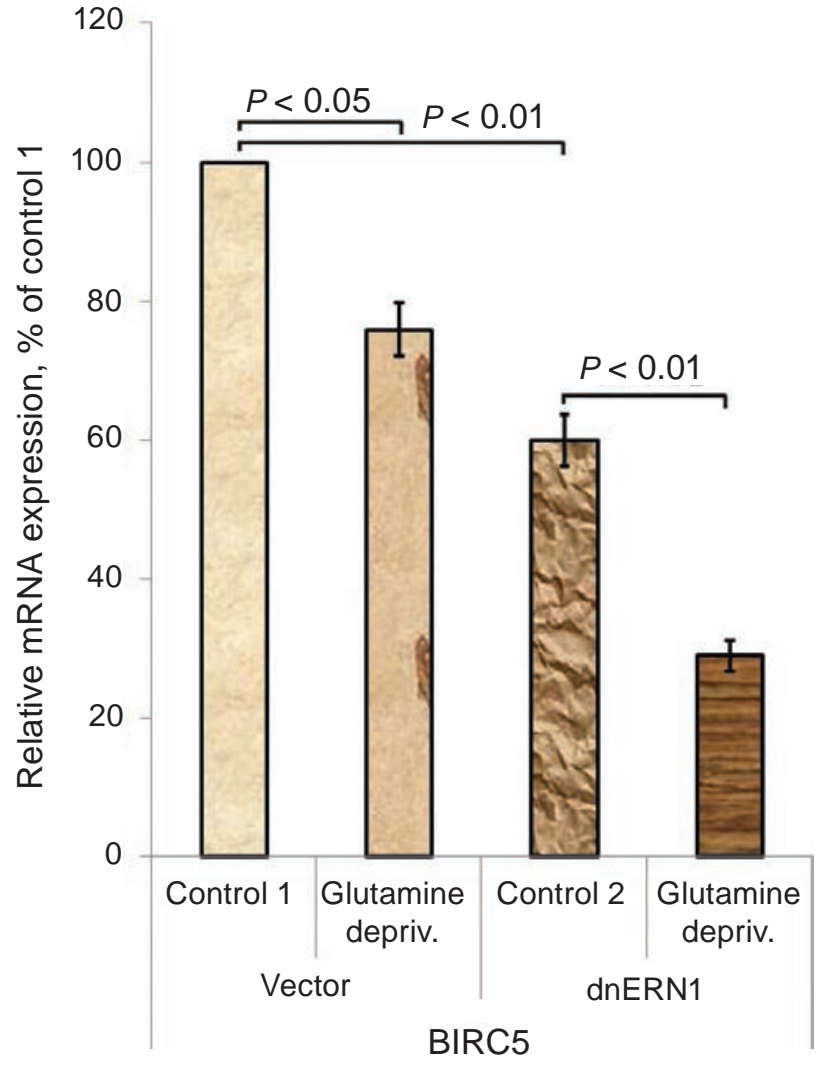

Fig. 4. Effect of glutamine deprivation on the expression level of BIRC5 (baculoviral IAP repeatcontaining 5) mRNA in control U87 glioma cells (Vector) and cells with a blockade of the ERN1 (dnERN1). Values of BIRC5 mRNA expressions were normalized to $\beta$-actin $m R N A$ level and represented as percent for control 1 (100\%); $n=4$

in glioma cells by dnERN1 eliminates effect of glutamine withdrawal on the expression RAB5C gene and enhances the sensitivity of BIRC5 gene expression to this condition.

Furthermore, inhibition of ERN1 leads to significant down-regulation of BIRC5 and RAB5C mRNA expressions in glioma cells growing with glutamine: $-40 \%$ for $B I R C 5$ gene and $-77 \%$ for RAB5C gene (Fig. 4 and 5). Thus, these results clearly demonstrated that glutamine deprivation has similar suppressive effect on the expression level of BIRC5 and RAB5C genes in control U87 glioma cells and that inhibition of ERN1 signaling enzyme function by dnERN1 modifies the effect of glutamine withdrawal on the expression of both these genes.

Next, we have studied the effect of glutamine deprivation on the expression of HSPB8 and HSPA5 genes in control as well as in ERN1 knockdown gli-

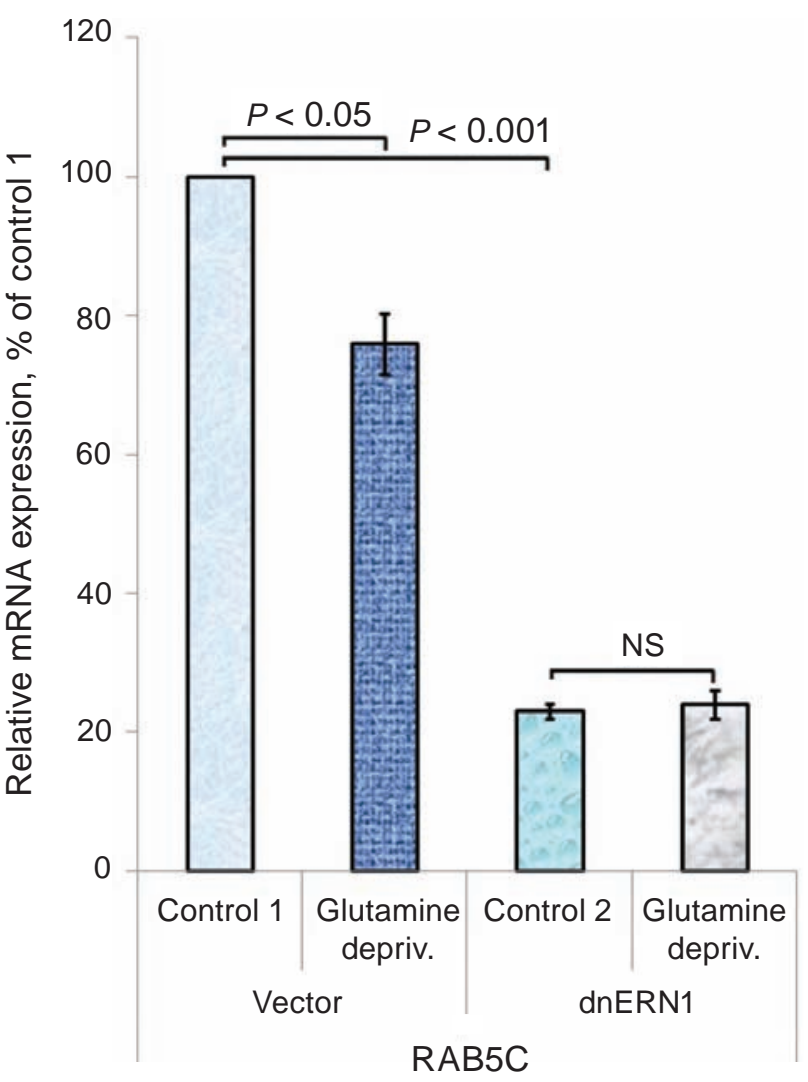

Fig. 5. Effect of glutamine deprivation on the expression level of RAB5C (RAB5C, member RAS oncogene family) mRNA in control U87 glioma cells (Vector) and cells with a blockade of the ERN1 (dnERN1). Values of RAB5C mRNA expressions were normalized to $\beta$-actin $m R N A$ level and represented as percent for control 1 (100\%); $n=4$

oma cells (Fig. 6 and 7). It was shown that glutamine withdrawal did not significantly change the expression of both genes, but inhibition of ERN1 introduces sensitivity of HSPA5 gene expression to glutamine deprivation (Fig. 7). At the same time, inhibition of ERN1 signaling did not significantly affect the expression of HSPB8 gene in glioma cells. As shown in Fig. 6 and 7, inhibition of ERN1 in glioma cells growing with glutamine significantly reduces the expression of HSPA5 gene (-26\% as compared to control 1) and strongly down-regulated HSPB8 gene expression (-86\% as compared to control 1).

Thus, we have shown that inhibition of ERN1 signaling significantly reduces the expression of most studied genes, which encoded proteins with pro-proliferative properties. It is possible that expression of these genes is regulated by XBP1 transcription factor, activated by ERN1 [7, 10, 12, 44]. 


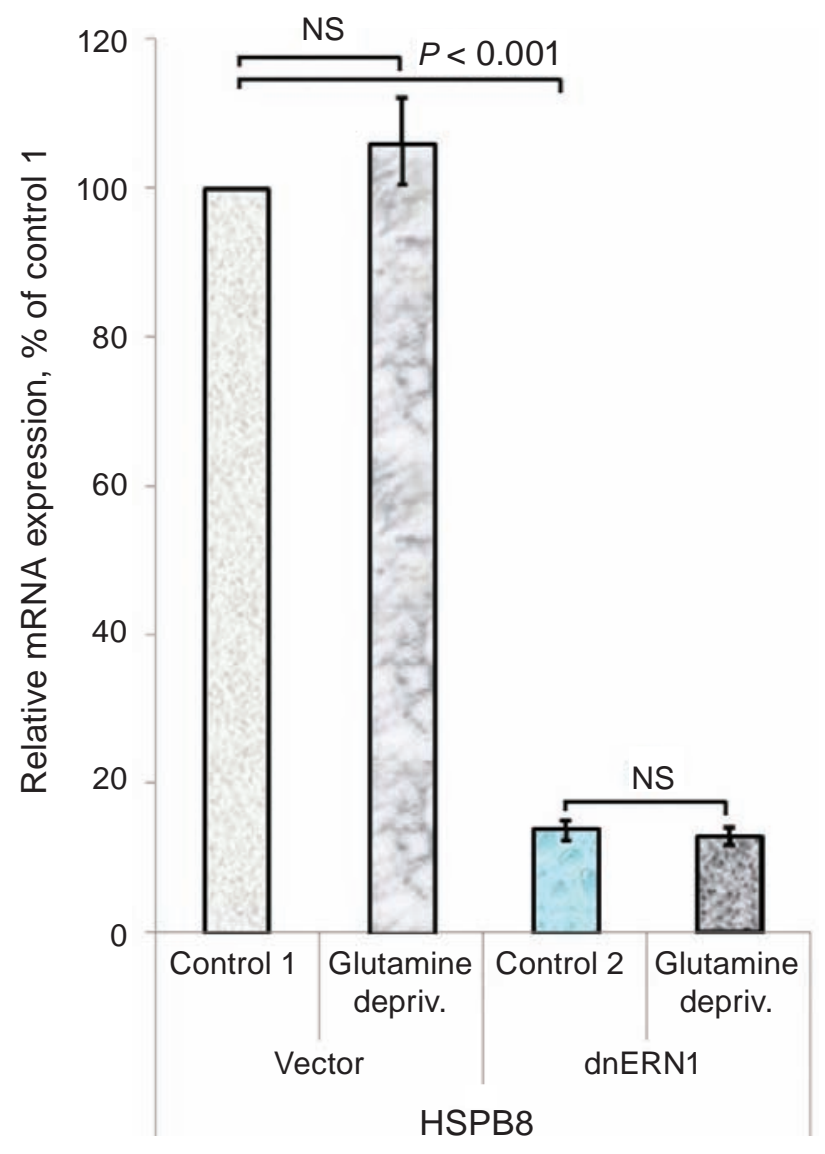

Fig. 6. Effect of glutamine deprivation on the expression level of HSPB8 (heat shock $22 \mathrm{kDa}$ protein 8) mRNA in control U87 glioma cells (Vector) and cells with a blockade of the ERN1 (dnERN1). Values of HSPB8 mRNA expressions were normalized to $\beta$-actin mRNA level and represented as percent for control 1 (100\%); $n=4$

Bioinformatics analysis of the presence of XBP1responsive motif (CCACG-box) in the promoter region of BIRC5, RAB5C, EIF2AK3, HSPA5, ATF6, HSPB8, and GLO1 genes shown that most of these genes have one or several potential XBP1 binding sites preferentially upstream of the transcription start site (Table). At the same time, we did not identified XBP1 binding sites in the promoter region of GLO1 and $H S P B 8$ genes. It is possible that ERN1 mediated regulation of these genes expression is mediated through protein kinase of ERN1 like epiregulin and some other genes [7, 13].

Summarized effect of glutamine deprivation on the expression of genes encoding important proliferation related regulatory factors, such as ATF6, EIF2AK3/PERK, GLO1, BIRC5/survivin, RAB5C, HSPB8/H11, and HSPA5/BiP/GRP78, in the control and ERN1 knockdown glioma cells is represented in Fig. 8. Glutamine withdrawal down-regulated the expression of most studied factors and these results completely agree with functional activity of ATF6, EIF2AK3/PERK, GLO1, BIRC5/survivin, and RAB5C proteins, which shown pro-proliferative effects [16-18, 24-32].

ATF6 and EIF2AK3 are important signaling proteins of endoplasmic reticulum stress signaling pathways [5]. The functional activity of these signaling proteins is increased in malignant tumors possibly through the regulation of glutaminase expression by the oncogenic transcription factor c-Jun [45]. Thus, glutamine withdrawal leads to downregulation of ATF6 and EIF2AK3 gene expressions

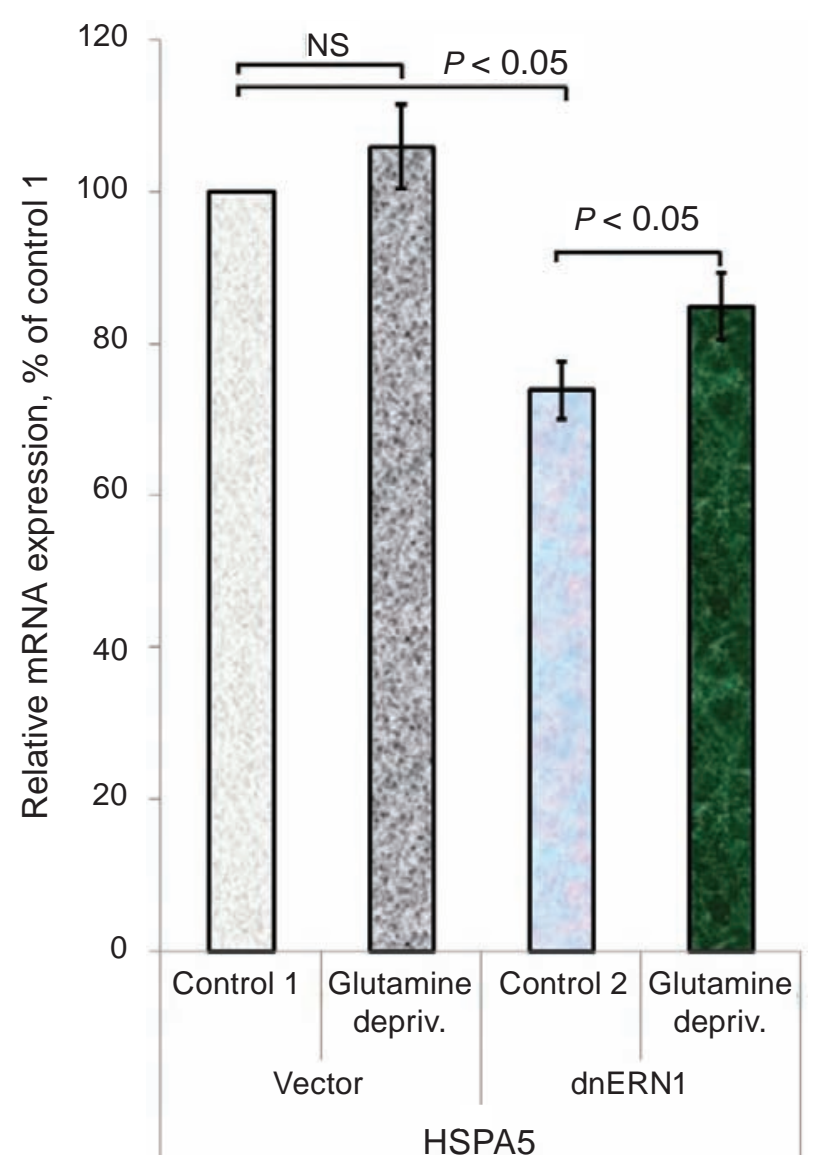

Fig. 7. Effect of glutamine deprivation on the expression level of HSPA5 (heat shock protein family A (Hsp70) member 5), also known as GRP78 (glucose regulated protein 78 ) and BiP (immunoglobulin heavy chain-binding protein), mRNA in control U87 glioma cells (Vector) and cells with a blockade of the ERN1 (dnERN1). Values of HSPA5 mRNA expressions were normalized to $\beta$-actin $m R N A$ level and represented as percent for control 1 (100\%); $n=4$ 
Matches for XBP1 CCACG-box (XBP1-responsive motif) in the promoter region of BIRC5, RAB5C, EIF2AK3, HSPA5, ATF6, HSPB8, and GLO1 genes

\begin{tabular}{l|c|c|c}
\hline \multicolumn{1}{c|}{ Gene symbol } & $\begin{array}{c}\text { Position relative to the } \\
\text { transcription start site }\end{array}$ & Sequence match & $\begin{array}{c}\text { Web site of promoter } \\
\text { sequence }\end{array}$ \\
\hline BIRC5 & -298 to -294 & aCCACGcc & 1 \\
BIRC5 & -68 to -64 & aCCACGgg & 1 \\
BIRC5 & -56 to -52 & gCCACGcg & 1 \\
RAB5C & -676 to -672 & aCCACGtt & 2 \\
EIF2AK3/ PERK & 154 to 157 & gaCGTGGc & 3 \\
HSPA5/BiP/GRP78 & -8 to -4 & tCCACGac & 4 \\
HSPA5/BiP/GRP78 & -676 to -672 & acCGTGGg & 4 \\
ATF6 & -305 to -301 & gCCACGct & 5 \\
ATF6 & -853 to -849 & tCCACGtg & 5 \\
ATF6 & -850 to -846 & caCGTGGt & 5 \\
HSPB8/H11 & & Not identified & 6 \\
GLO1 & & Not identified & 7 \\
\hline
\end{tabular}

1- http://switchdb.switchgeargenomics.com/productinfo/id_721013/;

2 - http://switchdb.switchgeargenomics.com/productinfo/id_719552/;

3 - http://switchdb.switchgeargenomics.com/productinfo/id_ $705088 /$;

4 - http://switchdb.switchgeargenomics.com/productinfo/id_719178/;

5 - http://switchdb.switchgeargenomics.com/productinfo/id_711611/;

6 - http://switchdb.switchgeargenomics.com/productinfo/id_707887/;

7 - http://switchdb.switchgeargenomics.com/productinfo/id_718376/

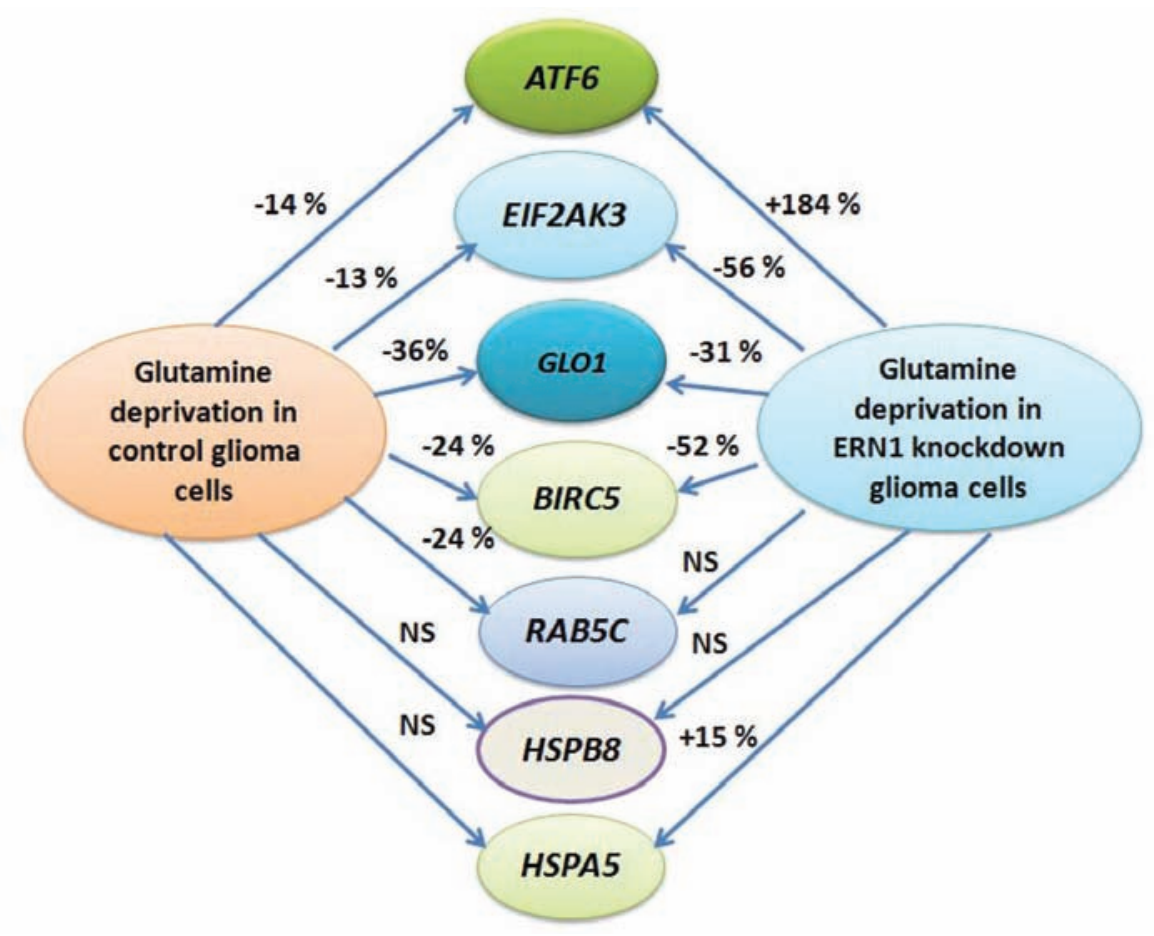

Fig. 8. Schematic representation of the effect of glutamine deprivation on the expression of genes encoding important proliferation related regulatory factors, such as ATF6, EIF2AK3/PERK, GLO1, BIRC5/survivin, RAB5C, HSPB8/H11, and HSPA5/BiP/GRP78, in the control and ERN1 knockdown glioma cells; NS - no significant changes 
and correlates with suppression of tumor cell proliferation $[17,46]$. Our results concerning suppression of BIRC5 and RAB5C gene expressions in glioma cells after glutamine withdrawal completely agree with functional activity of proteins encoded by these genes as well as with biological significance of glutamine for glioma cells growth [15-17, 40-42, 45]. Furthermore, significant down-regulation of the expression level by glucose deprivation was shown for GLO1 gene, which has strong relation to the control of tumor growth [31-34]. Our results agree with data Hutschenreuther et al. [33] that glutamine withdrawal decreases GLO1. Recently was shown that the expression of GLO1 is increased in some cancers and plays a pro-tumor role, participates in epithelial-to-mesenchymal transition, transformation into a neoplastic-like phenotype [25, 34]. This enzyme metabolizes methylglyoxal, a cytotoxic metabolite, which induces the formation of advanced glycation of end-products and is increased in cancer [26]. It was also shown that knockdown of GLO1 in the cancer cells increases methylglyoxal level and significantly reduced tumor-associated properties such as migration and proliferation [26]. Therefore, our results concerning strong down-regulation of GLO1 gene expressions in glioma cells upon inhibition of ERN1 as well as upon glutamine withdrawal completely agree with functional role of this protein in tumor cells and with suppression of ERN1 knockdown glioma cell proliferation [7, 12, 22, 25, 26].

Therefore, the changes in expression level of genes encoding ATF6, EIF2AK3/PERK, GLO1, BIRC5/survivin, RAB5C, HSPB8, and HSPA5/BiP/ GRP78 proteins possibly reflect metabolic reprogramming of glioma cells by glutamine deprivation as well as ERN1-mediated endoplasmic reticulum stress signaling and correlate with suppression of glioma cell proliferation upon inhibition of the ERN1 signaling enzyme.

\section{IRE1 ЗМІНЮС ЕФЕКТ ДЕФІЦИТУ \\ ГЛУТАМІНУ НА ЕКСПРЕСІЮ ФАКТОРІВ РОСТУ ПУХЛИН У КЛІТИНАХ ГЛІОМИ ЛІНІЇ U87}

О. Г. Мінченко, А. П. Харькова,

О. С. Гнатюк, О. Я. Лузіна, I. В. Кривдюк, А. Ю. Кузнєцова

\author{
Інститут біохімії ім. О. В. Палладіна \\ НАН України, Київ; \\ e-mail: ominchenko@yahoo.com
}

У роботі досліджували експресію групи генів, що кодують важливі протеїни в клітинах гліоми лінії U87 в умовах пригнічення функції ERN1 (endoplasmic reticulum to nucleus signaling 1) та дефіциту глутаміну. Показано, що за умов дефіциту глутаміну знижувався рівень експресії мPHК ATF6 (activating transcription factor 6), EIF2AK3/PERK (eukaryotic translation initiation factor 2 alpha kinase 3), GLO1 (glyoxalase I), BIRC5 (baculoviral IAP repeat-containing 5) та RAB5C (RAB5C, a member of RAS oncogene family) в контрольних клітинах гліоми. В той самий час, рівень експресії мРНК HSPB8 (heat shock $22 \mathrm{kDa}$ protein 8) та HSPA5/GRP78 (heat shock protein family A (Hsp70) member 5) був резистентним до дефіциту глутаміну в цих клітинах гліоми. Пригнічення ERN1 модифікувало ефект дефіциту глутаміну на рівень експресії більшості досліджених генів у клітинах гліоми лінії U87: збільшувало експресію генів ATF6 і HSPA5 та посилювало чутливість генів EIF2AK3 і BIRC5 до дефіциту глутаміну. Більше того, експресія досліджених генів (за винятком EIF2AK3) знижувалася в клітинах гліоми 3 пригніченим ERN1 у присутності глутаміну. Показано, що дефіцит глутаміну змінює експресію більшості досліджених генів залежно від ERN1 і ці зміни, можливо, причетні до пригнічення росту гліом iз клітин без функціональної активності сигнального ензиму ERN1.

К л ю чо в і с ло в а: дефіцит глутаміну, пригнічення ERN1, експресія мРНК, ATF6, EIF2AK3, BIRC5, RAB5C, HSPA5, клітини гліоми лінії U87. 


\section{IRE1 ИЗМЕНЯЕТ ЭФФЕКТ ДЕФИЦИТА ГЛУТАМИНА НА ЭКСПРЕССИЮ ФАКТОРОВ РОСТА ОПУХОЛЕЙ В КЛЕТКАХ ГЛИОМЫ ЛИНИИ U87}

\author{
О. Г. Минченко, А. П. Харькова, \\ О. С. Гнатюк, О. Я. Лузина, И. В. Кривдюк, \\ А. Ю. Кузнеиова
}

\author{
Институт биохимии им. А. В. Палладина \\ НАН Украины, Киев; \\ e-mail: ominchenko@yahoo.com
}

В работе изучали экспрессию генов, кодирующих важные протеины, в клетках глиомы линии U87 при угнетении функции ERN1 (endoplasmic reticulum to nucleus signaling 1) и дефиците глутамина. Показано, что при дефиците глутамина снижался уровень экспрессии мРНК ATF6 (activating transcription factor 6), EIF2AK3/ PERK (eukaryotic translation initiation factor 2 alpha kinase 3), GLO1 (glyoxalase I), BIRC5 (baculoviral IAP repeat-containing 5) и RAB5C (RAB5C, a member of RAS oncogene family) в контрольных клетках глиомы. В то же время, уровень экспрессии мРНК HSPB8 (heat shock $22 \mathrm{kDa}$ protein 8) и HSPA5/GRP78 (heat shock protein family A (Hsp70) member 5) был резистентным к дефициту глутамина в этих клетках глиомы. Угнетение ERN1, модифицировало эффект дефицита глутамина на уровень экспрессии большинства изученных генов в клетках глиомы линии U87: увеличивало экспрессию генов ATF6 и HSPA5 и усиливало чувствительность генов EIF2AK3 и BIRC5 к дефициту глутамина. Более того, экспрессия исследуемых генов (за исключением EIF2AK3) снижалась в клетках глиомы при угнетении ERN1 в присутствии глутамина. Показано, что дефицит глутамина изменяет экспрессию большинства изученных генов в зависимости от ERN1 и эти изменения, возможно, причастны к угнетению роста глиом из клеток без функциональной активности сигнального энзима ERN1.

Кл ю че вы е с лов а: дефицит глутамина, угнетение ERN1, экспрессия мРНК, ATF6, EIF2AK3, BIRC5, RAB5C, HSPA5, клетки глиомы линии U87.

\section{References}

1. Lieberman F. Glioblastoma update: molecular biology, diagnosis, treatment, response assessment, and translational clinical trials. F1000Res. 2017; 6: 1892.

2. Pearson JRD, Regad T. Targeting cellular pathways in glioblastoma multiforme. Signal Transduct Target Ther. 2017; 2: 17040.

3. Lara-Velazquez M, Al-Kharboosh R, Jeanneret S, Vazquez-Ramos C, Mahato D, Tavanaiepour D, Rahmathulla G, QuinonesHinojosa A. Advances in brain tumor surgery for glioblastoma in adults. Brain Sci. 2017; 7(12). pii: E166.

4. Galmiche A, Sauzay C, Chevet E, Pluquet O. Role of the unfolded protein response in tumor cell characteristics and cancer outcome. Curr Opin Oncol. 2017; 29(1): 41-47.

5. Obacz J, Avril T, Le Reste PJ, Urra H, Quillien V, Hetz C, Chevet E. Endoplasmic reticulum proteostasis in glioblastoma-From molecular mechanisms to therapeutic perspectives. Sci Signal. 2017; 10(470). pii: eaal2323.

6. Valdés-Rives SA, Casique-Aguirre D, GermánCastelán L, Velasco-Velázquez MA, GonzálezArenas A. Apoptotic Signaling Pathways in Glioblastoma and Therapeutic Implications. Biomed Res Int. 2017; 2017: 7403747.

7. Auf G, Jabouille A, Delugin M, Guérit S, Pineau R, North S, Platonova N, Maitre M, Favereaux A, Vajkoczy P, Seno M, Bikfalvi A, Minchenko D, Minchenko O, Moenner M. High epiregulin expression in human U87 glioma cells relies on IRE1 $\alpha$ and promotes autocrine growth through EGF receptor. BMC Cancer. 2013; 13: 597.

8. Minchenko OH, Tsymbal DO, Minchenko DO. IRE-1alpha signaling as a key target for suppression of tumor growth. Single Cell Biol. 2015; 4(3): 118.

9. Lhomond S, Avril T, Dejeans N, Voutetakis K, Doultsinos D, McMahon M, Pineau R, Obacz J, Papadodima O, Jouan F, Bourien H, Logotheti M, Jégou G, Pallares-Lupon N, Schmit K, Le Reste PJ, Etcheverry A, Mosser J, Barroso K, Vauléon E, Maurel M, Samali A, Patterson JB, Pluquet O, Hetz C, Quillien V, Chatziioannou A, Chevet E. Dual IRE1 RNase functions dictate glioblastoma development. EMBO Mol Med. 2018. pii: e7929. 
10. Chevet E, Hetz C, Samali A. Endoplasmic reticulum stress-activated cell reprogramming in oncogenesis. Cancer Discov. 2015; 5(6): 586597.

11. Minchenko DO, Kubaichuk KI, Ratushna OO, Komisarenko SV, Minchenko OH. The vascular endothelial growth factor genes expression in glioma U87 cells is dependent from ERN1 signaling enzyme function. Adv Biol Chem. 2012; 2(2): 198-206.

12. AufG, Jabouille A, Guérit S, Pineau R, Delugin M, Bouchecareilh M, Magnin N, Favereaux A, Maitre M, Gaiser T, von Deimling A, Czabanka M, Vajkoczy P, Chevet E, Bikfalvi A, Moenner M. Inositol-requiring enzyme lalpha is a key regulator of angiogenesis and invasion in malignant glioma. Proc Natl Acad Sci USA. 2010; 107(35): 15553-15558.

13. Minchenko OH, Tsymbal DO, Minchenko DO, Moenner M, Kovalevska OV, Lypova NM. Inhibition of kinase and endoribonuclease activity of ERN1/IRE1 $\alpha$ affects expression of proliferationrelated genes in U87 glioma cells. Endoplasm Reticul Stress Dis. 2015; 2(1): 18-29.

14. Minchenko DO, Riabovol OO, Ratushna OO, Minchenko $\mathrm{OH}$. Hypoxic regulation of the expression of genes encoded estrogen related proteins in U87 glioma cells: eff ect of IRE1 inhibition. Endocr Regul. 2017; 51(1): 8-19.

15. Alberghina L, Gaglio D. Redox control of glutamine utilization in cancer. Cell Death Dis. 2014; 5: e1561.

16. Yang S, Hwang S, Kim M, Seo SB, Lee JH, Jeong SM. Mitochondrial glutamine metabolism via GOT2 supports pancreatic cancer growth through senescence inhibition. Cell Death Dis. 2018; 9(2): 55.

17. Polet F, Corbet C, Pinto A, Rubio LI, Martherus R, Bol V, Drozak X, Grégoire V, Riant O, Feron O. Reducing the serine availability complements the inhibition of the glutamine metabolism to block leukemia cell growth. Oncotarget. 2016; 7(2): 765-1776.

18. Ma L, Tao Y, Duran A, Llado V, Galvez A, Barger JF, Castilla EA, Chen J, Yajima T, Porollo A, Medvedovic M, Brill LM, Plas DR, Riedl SJ, Leitges M, Diaz-Meco MT, Richardson AD, Moscat J. Control of nutrient stress-induced metabolic reprogramming by PKC $\zeta$ in tumorigenesis. Cell. 2013; 152(3): 599611.
19. Tsymbal DO, Minchenko DO, Kryvdiuk IV, Riabovo OO, Halkin OO, Ratushna OO, Minchenko OH. Expression of proliferation related transcription factor genes in U87 glioma cells with IRE1 knockdown: upon glucose and glutamine deprivation. Fiziol Zh. 2016; 62(1): 3-15.

20. Tsymbal DO, Minchenko DO, Riabovol OO, Ratushna OO, Minchenko OH. IRE1 knockdown modifies glucose and glutamine deprivation effects on the expression of proliferation related genes in U87 glioma cells. Biotechnologia Acta. 2016; 9(1): 26-37.

21. Riabovol OO, Tsymbal DO, Minchenko DO, Ratushna OO, Minchenko OH. IRE1 knockdown modifies the glutamine and glucose deprivation effect on the expression of nuclear genes encoding mitochondrial proteins in U87 glioma cells. Biotechnologia Acta. 2016; 9(2): 37-47.

22. Minchenko OH, Kharkova AP, Minchenko DO, Karbovskyi LL. Expression of IGFBP6, IGFBP7, NOV, CYR61, WISP1 and WISP2 genes in U87 glioma cells in glutamine deprivation condition. Ukr Biochem J. 2016; 88(3): 66-77.

23. Halkin OV, Minchenko DO, Riabovol OO, Telychko VV, Ratushna OO, Minchenko OH. Expression of ubiquitin specific peptidase and ATG7 genes in U87 glioma cells upon glutamine deprivation. Ukr Biochem J. 2017; 89(5): 52-61.

24. Bu LJ, Yu HQ, Fan LL, Li XQ, Wang F, Liu JT, Zhong F, Zhang CJ, Wei W, Wang H, Sun GP. Melatonin, a novel selective ATF-6 inhibitor, induces human hepatoma cell apoptosis through COX-2 downregulation. World J Gastroenterol. 2017; 23(6): 986-998.

25. Tungkum W, Jumnongprakhon $\mathrm{P}$, Tocharus $\mathrm{C}$, Govitrapong P, Tocharus J. Melatonin suppresses methamphetamine-triggered endoplasmic reticulum stress in C6 cells glioma cell lines. J Toxicol Sci. 2017; 42(1): 63-71.

26. Druelle C, Drullion C, Deslé J, Martin N, Saas L, Cormenier J, Malaquin N, Huot L, Slomianny C, Bouali F, Vercamer C, Hot D, Pourtier A, Chevet E, Abbadie C, Pluquet O. ATF6 $\alpha$ regulates morphological changes associated with senescence in human fibroblasts. Oncotarget. 2016; 7(42): 67699-67715.

27. Zhang M, Liu X, Wang Q, Ru Y, Xiong X, Wu K, Yao L, Li X. NDRG2 acts as a PERK co-factor to facilitate PERK branch and ERS-induced cell death. FEBS Lett. 2017; 591(21): 3670-3681. 
28. Wang SQ, Wang X, Zheng K, Liu KS, Wang SX, $\mathrm{Xie} \mathrm{CH}$. Simultaneous targeting PI3K and PERK pathways promotes cell death and improves the clinical prognosis in esophageal squamous carcinoma. Biochem Biophys Res Commun. 2017; 493(1): 534-541.

29. Márton M, Kurucz A, Lizák B, Margittai É, Bánhegyi G, Kapuy O. A Systems Biological View of Life-and-Death Decision with Respect to Endoplasmic Reticulum Stress-The Role of PERK Pathway. Int J Mol Sci. 2017; 18(1). pii: E58.

30. Guo Y, Zhang Y, Yang X, Lu P, Yan X, Xiao F, Zhou H, Wen C, Shi M, Lu J, Meng QH. Effects of methylglyoxal and glyoxalase I inhibition on breast cancer cells proliferation, invasion, and apoptosis through modulation of MAPKs, MMP9, and Bcl-2. Cancer Biol Ther. 2016; 7(2): 169-180.

31. Geng X, Ma J, Zhang F, Xu C. Glyoxalase I in tumor cell proliferation and survival and as a potential target for anticancer therapy. Oncol Res Treat. 2014; 37(10): 570-574.

32. Chiavarina B, Nokin MJ, Bellier J, Durieux F, Bletard N, Sherer F, Lovinfosse P, Peulen O, Verset L, Dehon R, Demetter P, Turtoi A, Uchida K, Goldman S, Hustinx R, Delvenne P, Castronovo V, Bellahcène A. MethylglyoxalMediated Stress Correlates with High Metabolic Activity and Promotes Tumor Growth in Colorectal Cancer. Int J Mol Sci. 2017; 18(1). pii: E213.

33. Hutschenreuther A, Bigl M, Hemdan NY, Debebe T, Gaunitz F, Birkenmeier G. Modulation of GLO1 Expression Affects Malignant Properties of Cells. Int J Mol Sci. 2016; 17(12). pii: E2133.

34. Antognelli C, Gambelunghe A, Muzi G, Talesa VN. Glyoxalase I drives epithelial-tomesenchymal transition via argpyrimidinemodified Hsp70, miR-21 and SMAD signalling in human bronchial cells BEAS-2B chronically exposed to crystalline silica Min-U-Sil 5: Transformation into a neoplastic-like phenotype. Free Radic Biol Med. 2016; 92: 110-125.

35. Wang C, Cai L, Liu J, Wang G, Li H, Wang X, $\mathrm{Xu}$ W, Ren $\mathrm{M}$, Feng L, Liu P, Zhang C. MicroRNA-30a-5p Inhibits the Growth of Renal Cell Carcinoma by Modulating GRP78 Expression. Cell Physiol Biochem. 2017; 43(6): 2405-2419.
36. Kang JM, Park S, Kim SJ, Kim H, Lee B, Kim J, Park J, Kim ST, Yang HK, Kim WH, Kim SJ. KIAA1324 Suppresses Gastric Cancer Progression by Inhibiting the Oncoprotein GRP78. Cancer Res. 2015; 75(15): 3087-3097.

37. Piccolella M, Crippa V, Cristofani R, Rusmini P, Galbiati M, Cicardi ME, Meroni M, Ferri N, Morelli FF, Carra S, Messi E, Poletti A. The small heat shock protein B8 (HSPB8) modulates proliferation and migration of breast cancer cells. Oncotarget. 2017; 8(6): 10400-10415.

38. Li XS, Xu Q, Fu XY, Luo WS. Heat shock protein 22 overexpression is associated with the progression and prognosis in gastric cancer. J Cancer Res Clin Oncol. 2014; 140(8): 13051313.

39. Acunzo J, Katsogiannou M, Rocchi P. Small heat shock proteins HSP27 (HspB1), $\alpha$ B-crystallin (HspB5) and HSP22 (HspB8) as regulators of cell death. Int J Biochem Cell Biol. 2012; 44(10): 1622-1631.

40. de Graaff MA, Malu S, Guardiola I, Kruisselbrink AB, de Jong Y, Corver WE, Gelderblom H, Hwu P, Nielsen TO, Lazar AJ, Somaiah N, Bovée JVMG. High-Throughput Screening of Myxoid Liposarcoma Cell Lines: Survivin Is Essential for Tumor Growth. Transl Oncol. 2017; 10(4): 546-554.

41. Igarashi $\mathrm{T}$, Araki $\mathrm{K}$, Yokobori $\mathrm{T}$, Altan $\mathrm{B}$, Yamanaka T, Ishii N, Tsukagoshi M, Watanabe A, Kubo N, Handa T, Hosouchi Y, Nishiyama M, Oyama T, Shirabe K, Kuwano H. Association of RAB5 overexpression in pancreatic cancer with cancer progression and poor prognosis via E-cadherin suppression. Oncotarget. 2017; 8(7): 12290-12300.

42. Tan YS, Kim M, Kingsbury TJ, Civin CI, Cheng WC. Regulation of RAB5C is important for the growth inhibitory effects of MiR-509 in human precursor-B acute lymphoblastic leukemia. PLoS One. 2014; 9(11): e111777.

43. Bochkov VN, Philippova M, Oskolkova O, Kadl A, Furnkranz A, Karabeg E, Afonyushkin T, Gruber F, Breuss J, Minchenko A, Mechtcheriakova D, Hohensinner P, Rychli K, Wojta J, Resink T, Erne P, Binder BR, Leitinger N. Oxidized phospholipids stimulate angiogenesis via autocrine mechanisms, implicating a novel role for lipid oxidation in the evolution of atherosclerotic lesions. Circ Res. 2006; 99(8): 900-908. 
44. Manié SN, Lebeau J, Chevet E. Cellular mechanisms of endoplasmic reticulum stress signaling in health and disease. 3. Orchestrating the unfolded protein response in oncogenesis: an update. Am J Physiol Cell Physiol. 2014; 307(10): C901-C907.

45. Lukey MJ, Greene KS, Erickson JW, Wilson KF, Cerione RA. The oncogenic transcription factor
c-Jun regulates glutaminase expression and sensitizes cells to glutaminase-targeted therapy. Nat Commun. 2016; 7: 11321.

46. Chen L, Cui H. Targeting Glutamine Induces Apoptosis: A Cancer Therapy Approach. Int J Mol Sci. 2015; 16(9): 22830-22855.

Received 19.03.2018 